\title{
ANALISIS KEMAMPUAN BERPIKIR KRITIS SISWA PADA MATA PELAJARAN MATEMATIKA
}

\author{
Olenggius Jiran Dores ${ }^{1,}$ Dwi Cahyadi Wibowo ${ }^{2}$ Susi Susanti $^{3}$ \\ ${ }^{1}$ Prodi Pendidikan Matematika, STKIP Persada Khatulistiwa Sintang \\ ${ }^{2,3}$ Prodi PGSD, STKIP Persada Khatulistiwa Sintang \\ email:10lenggius@gmail.com, ${ }^{2}$ dwicahyadiwibowo@yahoo.co.id, \\ susisusanty271@ gmail.com
}

\begin{abstract}
IV of state primary school 03 sebungkang a year of 2020/202. This research subject all 15 students from grade IV. The approach to this study is qualitative with qualitative research methods, while the form of this qualitative descriptive. according to research: 1) students critical thinking ability on mathematical subjects in grade IV SDN 03 sebungkang a bag of 29,58\% category was very low. Math indicator for discussion is $63,33 \%$, indicator presents the logical reasoning of concepts/ideas as valid and relevant evidence of 26,67\%, indicators deduce the relationship between ideas for solving a mathematical problem of 13,33\%, action indicators include a $15 \%$ mathematical solution. 2) the factors that affect a students critical thinking ability are psychological factors that consist of intellectual, motivational, and anxiety, physiological factors made up of physical conditions, learning self-reliance factors, and interaction factors. 3) the effort by teachers to improve students critical thinking ability is class management, using varying learning approaches and methods, creating interactions between teachers and students, and performing learning assessments.
\end{abstract}

Keywords : Ability analysis, critical thinking, mathematis,

\begin{abstract}
Abstrak.Penelitian ini bertujuan untuk mengetahui kemampuan berpikir kritis siswa pada mata pelajaran matematika dikelas IV Sekolah Dasar Negeri 03 Sebungkang tahun pelajaran 2020/2021. Subjek penelitian ini adalah seluruh siswa kelas IV SDN 03 sebungkang sebanyak 15 orang siswa. Pendekatan pada penelitian ini kualitatif dengan metode penelitian kualitatif sedangkan bentuk penelitian ini adalah deskriptif kualitatif. Berdasarkan hasil penelitian diperoleh: 1) kemampuan berpikir kritis siwa pada mata pelajaran matematika di kelas IV SDN 03 Sebungkang sebesar 29,58\% kategori sangat rendah. Memahami masalah matematis untuk didiskusikan sebesar 63,33\%, mengajukan alasan yang logis berupa konsep/ide sebagai bukti yang valid dan relevan sebesar 26,67\%,menyimpulkan hubungan antara ide-ide untuk menyelesaikan masalah matematis sebesar 13,33\%, dan mengambil tindakan berupa penyelesaian masalah matematis sebesar 15\%. 2) faktor-faktor yang mempengaruhi kemampuan berpikir kritis siswa yaitu faktor psikologis yang terdiri dari perkembangan intelektual, motivasi, dan kecemasan, Faktor fisiologis yang terdiri dari kondisi fisik, faktor kemandirian belajar, dan faktor interaksi. 3) upaya yang dilakukan guru untuk meningkatkan kemampuan berpikir kritis siswa yaitu pengelolaan kelas, menggunakan pendekatan dan metode pembelajaran yang bervariasi, menciptakan interaksi antara guru dan siswa, dan melakukan evaluasi pembelajaran.
\end{abstract}

Kata kunci : Analisis Kemampuan, Berpikir Kritis, Matematika 


\section{PENDAHULUAN}

Pendidikan merupakan usaha manusia untuk membina kepribadiannya sesuai dengan nilai-nilai di dalam masyarakat dan kebudayaan. Istilah pendidikan dan pedagogik berarti bimbingan yang diberikan dengan sengaja oleh orang dewasa agar ia menjadi dewasa. Pendidikan juga sebagai usaha yang dijalankan oleh seseorang dan sekelompok orang lain agar menjadi dewasa mencapai tingkat hidup yang lebih tinggi dalam arti mental.

Hasbullah (2017:4) menyatakan bahwa "pendidikan merupakan perbuatan manusiawi, pendidikan lahir dari pergaulan antar orang dewasa dan orang belum dewasa dalam satu kesatuan hidup". Tindakan mendidik yang dilakukan oleh orang dewasa dengan sadar dan sengaja didasari oleh nilai-nilai kemanusian. Tindakan tersebut menyebabkan orang yang belum dewasa menjadi dewasa dengan memiliki nilai-nilai kemanusiaan, dan hidup menurut nilai-nilai tersebut. Kedewasaan diri merupakan tujuan pendidikan yang hendak dicapai melalui perbuatan atau tindakan pendidikan.

Seiring dengan perkembangan zaman, kemajuan teknologi yang semakin pesat menuntut pendidikan untuk terus berkembang dan dapat menghasilkan Sumber Daya Manusia (SDM) yang berkualitas tinggi yang mampu berpikir kritis, kreatif, sistematis, mampu dalam memecahkan masalah, dan mempunyai akhlak yang baik. Kemampuan berpikir kritis sangat penting dimiliki, karena berpikir kritis dapat digunakan untuk memecahkan masalah dan sebagai pertimbangan dalam pengambilan keputusan yang benar. Menurut Purwati (2016:84) Berpikir kritis merupakan sebuah proses, bertujuan untuk membuat keputusan yang masuk akal tentang apa yang dipercaya dan apa yang dilakukan .

Kemampuan berpikir kritis merupakan suatu hal yang sangat penting, namun kenyataan di lapangan belum sesuai dengan yang diharapkan. dilihat dari rancangan, pelaksanaan, dan proses pembelajaran di Sekolah Dasar belum ditujukan pada pengembangan kemampuan berpikir kritis peserta didik.

Berdasarkan hasil observasi dan wawancara yang dilakukan dengan guru wali kelas IV SDN 03 Sebungkang pada tanggal 19 maret 2020 kemampuan berpikir kritis siswa masih tergolong rendah, hal ini dilihat dari nilai matematika siswa, dari 15 siswa terdapat 5 atau 33,33 \% siswa yang mampu berpikir kritis, sedangkan 10 orang atau $66,67 \%$ siswa belum mampu berpikir kritis. Dari data yang diperoleh berdasarkan wawancara dengan guru wali kelas IV rendahnya kemampuan berpikir kritis siswa disebabkan oleh beberapa faktor diantaranya adalah 
siswa kurang konsentrasi dan tidak fokus terhadap pembelajaran yang disampaikan oleh guru, dalam proses pembelajaran siswa harus didorong oleh guru itu sendiri untuk mengajukan pertanyaan, siswa lebih banyak diam, duduk, mendengarkan, mencatat, dan menghafal sehingga kegiatan belajar mengajar menjadi tidak menarik dan menyenangkan. Pada saat siswa mengerjakankan soal matematika yang diberikan guru masih banyak siswa yang masih belum bisa memahami maksud dari soal tersebut dan cara untuk penyelesaiaannya, siswa kurang memahami konsep dari penyelesaian soal yang diberikan guru serta kurang mampu memecahkan masalah pada soal yang diberikan dan tingkat penalaran siswa juga masih kurang. Guru juga masih cenderung menggunakan metode konvensial selama pembelajaran matematika berlangsung. Hal ini sejalan dengan pendapat Zafri (Ermatiana, 2019:22-23) yang mengemukakan bahwa ada beberapa faktor yang mempengaruhi kemampuan berpikir kritis siswa diantaranya 1) kondisi fisik, kondisi fisik adalah kebutuhan fisiologis yang paling dasar bagi manusia, ketika kondisi fisik terganggu, sementara ia dihadapkan pada situasi yang menuntut pemikirannya yang matang untuk memecahkan suatu permasalahan kondisi tersebut sangat mempengaruhi pikirannya, ia tidak dapat berkonsentrasi dan berpikir cepat karena kondisi tubuhnya atau fisiknya tidak memungkinkan. 2) motivasi, motivasi adalah upaya untuk menimbulkan rangsangan, dorongan ataupun pembangkit tenaga seorang agar mau berbuat sesuatu atau memperlihatkan perilaku tertentu yang telah direncanakan untuk mencapai tujuan yang telah ditetapkan. 3) kecemasan, keadaan emosiaonal yang ditandai dengan kegelisahan dan ketakutan terhadap kemungkinana bahaya, kecemasan timbul secara otomatis jika individu menerima stimulus yang berlebihan. 4) perkembangan intelektual, intelektual merupakan kemampuan mental seseorang untuk merespon dan menyelesaikan suatu persoalan. Perkembangan intelektual setiap orang berbeda-beda disesuaikan dengan tingkat perkembangannya.

\section{METODE PENELITIAN}

Penelitian ini menggunakan metode kualitatif. Pendekatan penelitian kualitatif dengan bentuk deskriptif kualitatif. Menurut Moleong (2014:6) menyatakan bahwa "penelitian kualitatif adalah penelitian yang bermaksud untuk memahami fenomena tentang apa yang dialami oleh subjek penelitian misalnya perilaku, persepsi, motivasi, tindakan, secara holistik dan dengan cara deskripsi dalam bentuk kata-kata dan bahasa, pada suatu 
konteks khusus yang alamiah dan dengan memanfaatkan berbagai metode alamiah". Lokasi penelitian ini dilaksanakan di Sekolah Dasar Negeri 03 Sebungkang, yang beralamat di Desa Kebong, tepatnya di Dusun Sebungkang Kecamatan Kelam Permai, Kabupaten Sintang. Subyek penelitian ini adalah seluruh siswa kelas IV Sekolah Dasar Negeri 03 Sebungkang, yang berjumlah 15 orang.

Penelitian ini menggunakan teknik dan alat pengumpulan data yang berupa teknik pengukuran berupa soal tes, teknik komunikasi langsung berupa pedoman wawancara dan teknik dokumentasi berupa foto-foto dokumen resmi serta kegiatan selama penelitan. Teknik analisis data pada penelitian ini yaitu menggunakan teknik analisis data menurut Miles dan Haberman (Sugiyono 2016:246) mengemukakan bahwa "Aktivitas dalam analisis data kualitatif dilakukan secara interaktif dan berlangsung terus menerus sampai tuntas, sampai datanya sudah jenuh". Adapun aktivitas dalam analisis data penelitian ini yakni data collection, data reduction, data display dan data drawing/verification (Sugiyono, 2016:246).

\section{HASIL DAN PEMBAHASAN}

Hasil penelitian ini diperoleh melalui pengumpulan data berupa penyebaran tes, wawancara siswa dan guru. Adapun hasil dan pembahasan pada penelitian ini sebagai berikut:

\section{Kemampuan Berpikir Kritis Siswa}

Pada Mata Pelajaran Matematika

Berdasarkan hasil penyebaran soal tes kepada seluruh siswa kelas IV SDN 03 Sebungkang pada tanggal 14 Agustus 2020, ditemukan bahwa kemampuan berpikir kritis siswa pada mata pelajaran matematika masih tergolong sangat rendah. Hal ini dibuktikan melalui perolehan rata-rata hasil tes seluruh siswa kelas IV SDN 03 Sebungkang sebesar 29,58\%. Adapun persentase perolehan nilai setiap indikator kemampuan berpikir kritis siswa dapat dilihat pada gambar 1 diagram tingkat berpikir kritis siswa setiap indikator:

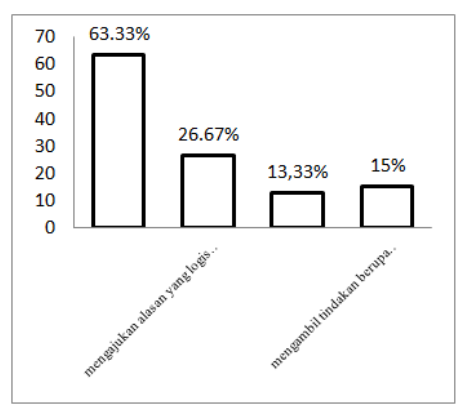

\section{Gambar 1 diagram tingkat berpikir kritis siswa setiap indikator}

Dari diagram di atas, diketahui bahwa persentase setiap indikator kemampuan berpikir kritis yang diukur yaitu: 1) indikator mengusulkan masalah matematis yang didiskusikan diketahui persentase sebesar $63,33 \%$.2) indikator mengajukan alasan logis berupa konsep/ide sebagai bukti yang valid dan relevan, diketahui persentase sebesar $26,67 \%$, skor tertinggi sebesar. 3) 
indikator menyimpulkan hubungan antara ide-ide untuk menyelesaikan masalah matematis, diketahui persentase sebesar $13,33 \%, 4)$ indikator mengambil tindakan berupa penyelesaian masalah matematis, persentase sebesar $15 \%$. Maka dari itu, dapat disimpulkan bahwa kemampuan berpikir kritis siswa pada mata pelajaran matematika di kelas IV SDN 03 Sebungkang masih relatif sangat rendah.

Pada proses pembelajaran siswa melakukan kegiatan berpikir. Berpikir merupakan aktivitas psikis yang dilakukan apabila seseorang mendapati permasalahan yang harus dipecahkan. Kemampuan berpikir kritis merupakan kemampuan dasar untuk memecahkan masalah. Hal ini didukung dengan pendapat dari Azizah (2018:62) kemampuan berpikir kritis adalah "proses kognitif siswa dalam menganalisis secara sistematis dan spesifik masalah yang dihadapi, membedakan masalah tersebut secara cermat dan teliti, serta mengudentifikasikan dan mengkaji informasi guna merencanakan strategi pemecahan masalah".

Faktor-Faktor yang Mempengaruhi

Kemampuan Berpikir Kritis Siswa

Pada Mata Pelajaran Matematika

Berdasarkan hasil wawancara yang dilakukan peneliti dengan 9 orang siswa pada tanggal 14 Agustus 2020, ditemukan sebagai berikut:
1. Faktor psikologi

a. Perkembangan Intelektual Berdasarkan hasil penelitian yang dilakukan oleh peneliti, siswa yang memiliki perkembangan intelektual tinggi mampu untuk memahami materi pelajaran dengan cepat dan mampu memahami soal yang diberikan. Siswa yang memiliki perkembangan intelektual yang sedang ada beberapa orang ssiwa yang sudah mampu untuk memahami materi pelajaran dengan cepat dan mampu memahami soal yang diberikan, sedangkan siswa yang memiliki perkembangan intelektual yang rendah siswa tidak mampu untuk memahami materi pelajaran dengan cepat dan mampu memahami soal yang diberikan. Hal ini berkaitan dengan pendapat Zafri (Ermatiana 2019:22-23) mengemukan bahwa Perkembangan intelektual atau kecerdasan merupakan kemampuan mental seseorang untuk merespon dan menyelesaikan suatu persoalan, menghubungkan suatu hal dengan yang lain dan dapat merespon dengan baik setiap stimulus, perkembangan intelektual tiap orang berbeda- 
beda disesuaikan dengan usia dan tingkat perkembanganya.

b. Motivasi

$$
\text { Berdasarkan hasil }
$$
penelitian yang dilakukan oleh peneliti, diketahui bahwa siswa merasa termotivasi dan mempunyai tekad serta minat yang kuat untuk belajar matematika dengan baik dikarena siswa merasa tertantang untuk belajar matematika, siswa juga mempunyai rasa ingin tahu yang kuat untuk belajar matematika. Orangtua siswa juga memberikan dukungan dan motivasi sehingga siswa mempunyai tekad serta minat yang kuat untuk belajar matematika. Hal ini sejalan dengan pendapat Prameswari (2019:746) mengemukakan bahwa tingkat perkembangan intelektual siswa berbeda antara satu siswa dengn yang lainnya, perekembangan intelektual dipengaruhi oleh tingkat perkembangannya. Dari pendapat tersebut disimpulkan bahwa perkembangan intelektual mempengaruhi kemampuan berpikir kritis siswa.

c. Kecemasan
Berdasarkan hasil penelitian yang dilakukan oleh peneliti, bahwa beberapa orang siswa merasa takut atau tidak berani dalam mengajukan pendapat maupun bertanya dan memberikan penjelasan terhadap materi pelajaran yang belum dipahaminya kepada guru, siswa merasa malu untuk bertanya kepada guru jika salah dan takut dimarahi oleh guru. hal ini sejalan dengan pendapat Zafri (Ematiana 2019:22-23) mengemukakan bahwa kecemasan merupakan keadaan emosional siswa yang ditandai dengan kegelisahan dan ketakutan terhadap kemungkinan bahaya, kecemasan timbul secara otomatis jika individu menerima stimulus berlebihan yang melampaui batas untuk menanganinya. Reaksi terhadap kecemasan dapat bersifat konstruktif yaitu memotivasi individu untuk belajar dan mengadakan perubahan terutama perubahan perasaan tidak nyaman, serta terfokus pada kelangsungan hidup, reaksi destruktif yaitu menimbulkan tingkah laku maladaptif dan disfungsi yang menyangkut kecemasan berat atau panik 
serta dapat membatasi seseorang dalam berpikir.

2. Faktor fisiologi

a. Kondisi fisik

$$
\text { Berdasarkan }
$$

hasil penelitian yang dilakukan oleh peneliti, bahwa ada beberapa siswa yang tidak dapat untuk berkonsentrasi selama pembelajaran berlangsung, siswa merasa terganggu saat proses pembelajaran sehingga menyebabkan siwa sulit untuk memahamai materi pelajaran yang disampaikan oleh guru sehingga siswa tidak dapat berpikir cepat dalam memahami pelajaran yang disampaikan oleh guru hal ini mempengaruhi kemampuan berpikir kritis siswa. Zafri (Ematiana 2019:22-23) mengemukakan bahwa kondisi fisik adalah kebutuhan fisiologi yang paling dasar bagi manusia untuk menjalani kehidupan. Ketika kondisi fisik siswa terganggu, sementara ia dihadapkan pada situasi yang menuntut pemikiran yang matang untuk memecahkan sesuatu masalah maka kondisi seperti ini sangat

$\begin{array}{lr}\text { mempengaruhi } & \text { pikiran } \\ \text { siswa, } & \text { ia }\end{array}$ berkonsentrasi dan berpikir cepat karena tubuhnya tidak memungkinkan untuk bereaksi terhadap respon yang ada.

3. Faktor kemandirian belajar

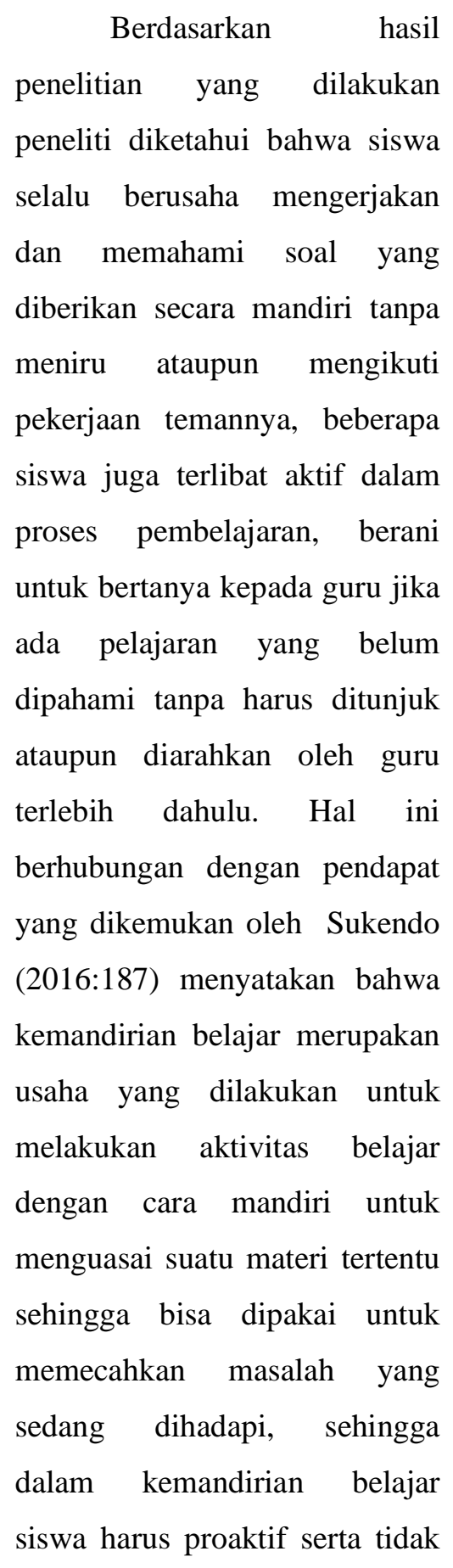


tergantung pada guru.

kemandirian belajar siswa akan menuntut siswa untuk aktif baik sebelum maupun sesudah pembelajaran berlangsung. Kemandirian belajar siswa juga meunutut siswa untuk berpikir lebih kuat dan kritis karena dihadapkan agar berpartisipasi aktif didalam proses pembelajaran.

4. Faktor interaksi Interaksi mempunyai pengaruh yang cukup penting dalam perkembangan kemampuan berpikir kritis siswa. Interaksi yang baik antara guru dan siswa dapat membantu mengembangkan kemampuan berpikir kritis siswa. Berdasarkan hasil penelitian yang dilakukan oleh peneliti diketahui interaksi antara guru dan siswa terjalin baik, guru memberikan arahan serta penjelasan yang baik kepada siswa selama proses pembelajaran, siswa dibimbing oleh guru baik secara individu maupun kelompok, siswa diberi kesempatan untuk bertanya oleh guru jika ada materi yang belum dipahami, dalam proses pembelajaran guru juga melakukan pendekatan kepada siswa yang sangat sulit untuk memahami pelajaran yang disampaikan, guru berusaha menciptakan lingkungan belajar yang kondusif dengan menggunakan berbagai media pembelajaran serta metode pembelajaran sehingga siswa semangat di dalam proses belajar mengajar. Hal ini berkaitan dengan pendapat Prameswari (2018:47) yang mengemukakan bahwa salah satu faktor yang dapat mempengaruhi perkembangan kemampuan berpikir kritis siswa adalah interaksi antara pengajar dan siswa. Suasana pembelajaran yang kondusif dapat meningkatkan semangat siswa dalam proses pembelajaran sehingga siswa berkonsentrasi dalam memecahkan masalah yang diberikan.

\section{Upaya Guru Dalam Meningkatkan}

Kemampuan Berpikir Kritis Siswa Pada Mata Pelajaran Matematika

Berdasarkan hasil wawancara dengan guru wali kelas IV pada tanggal 15 Agustus 2020, ditemukan sebagai berikut:

1. Pengelolaan kelas

Pengelolaan kelas adalah salah satu tugas guru yang tidak pernah ditinggalkan, guru selalu mengelola kelas ketika 
melaksanakan tugasnya. Dari hasil penelitian yang dilakukan diketahui bahwa pada saat pembelajaran berlangsung guru menciptakan suasana kelas yang kondusif dengan menggunakan pendekatan serta metode pembelajaran untuk membantu siswa memahami materi pelajaran yang disampaikan dengan mudah serta merangsang berpikir siswa, guru juga membimbing siswa baik secara individu maupun kelompok selama proses pembelajaran, guru membantu siswa yang merasa kesulitan dalam memahami materi yang diberikan sehingga siswa dapat memahami pelajaran yang disampaikan dan mampu memecahkan masalah yang dihadapi selama pelajaran berlangsung, selain itu guru juga mengenali karakteristik siswa sehingga dengan mudah untuk menciptakan suasana belajar yang kondusif yang mengarah untuk mencapai tujuan pembelajaran yang diharapkan. Hal ini sejalan dengan yang dikatakan Nuraida (2019:55) yang mengemukakan bahwa seorang guru harus menciptakan suasana kelas yang menantang untuk memfasilitasi meningkatnya kemampuan berpikir kritis, penciptaan suasana kelas yang menantang ini tentu saja berkaitan dengan metode maupun model mengajar yang dipilih guru. dengan demikian pengelolaan kelas dapat meningkatkan kemampuan berpikir kritis siswa.

2. Menggunakan Metode dan Pendekatan Pembelajaran yang Bervariasi

pendekatan dan metode pembelajaran merupakan salah satu cara yang digunakan guru dalam proses belajar mengajar agar memudahkan guru maupun siswa untuk mencapai tujuan pembelajaran yang diharapkan. hasil penelitian yang dilakukan oleh peneliti, bahwa dalam meningkatkan kemampuan berpikir kritis siswa guru menggunakan pendekatan pembelajaran yaitu pendekatan saintifik dan metode pembelajaran kooperatif, tanya jawab, dan penugasan. Penggunaan pendekatan dan metode pembelajaran dapat membantu siswa agar mudah memahami materi pelajaran yang disampaikan. Saat guru menerapkan pendekatan dan metode pembelajaran tersebut 
guru mempertimbangkan

kemampuan siswa, karena siswa mempunyai kemampuan yang berbeda-beda. Hal ini juga berkaitan dengan pendapat Nuraida (2019:55) yang menyatakan bahwa penggunaan metode pembelajaran yang inovatif sangat berpotensi untuk meningkatkan dan melatih berpikir kritis siswa dalam pembelajaran. Dengan demikian penggunaan pendekatan dan metode pembelajaran dapat meningkatkan kemampuan berpikir kritis siswa.

3. Menciptakan interaksi yang baik antara guru dan siswa

Interaksi merupakan hubungan setiap orang baik langsung maupun tidak langsung. Menciptakan dan mendorong adanya interaksi diantara dan siswa menunjukan bahwa berpikir kritis melibatkan proses sosial. Berdasarkan Hasil penelitian diketahui bahwa guru memberikan kebebasan kepada siswa untuk mengemukakan pendapat dan bertanya jika ada materi pelajaran yang belum dipahami selama pelajaran berlangsung, guru membimbing siswa untuk memahami pelajaran yang disampaikan sehingga siswa mampu untuk memecahkan masalah pada materi pelajaran yang dipelajari. Berdasarkan hal ini maka terciptanya interaksi antara guru dan siswa dapat meningkatkan kemampuan berpikir kritis siswa. Menurut Rath (Nuraida, 2019:55) mengemukakan bahwa salah satu cara yang dilakukan guru untuk meningkatkan serta mengembangkan kemampuan berpikir kritis yaitu adanya interaksi adalah pengajar dan siswa, oleh karena itu suasana belajar mengajar harus memberikan kebebasan dan rasa aman kepada siswa untuk mengekspresikan pendapat selama kegiatan belajar mengajar berlangsung. Hal ini berkaitan dengan hasil penelitian yang dilakukan oleh peneliti, yang menyatakan bahwa guru memberikan kebebasan kepada siswa untuk mengemukakan pendapat dan bertanya jika ada materi pelajaran yang belum dipahami selama pelajaran berlangsung, guru membimbing siswa untuk memahami pelajaran yang disampaikan sehingga siswa mampu untuk memecahkan masalah pada materi pelajaran yang dipelajari. Berdasarkan hal 
ini maka terciptanya interaksi antara guru dan siswa dapat meningkatkan kemampuan berpikir kritis siswa.

4. Melakukan evaluasi/latihan pembelajaran

Evaluasi pembelajaran merupakan proses yang dilakukan guru untuk mengetahui tingkat pencapain siswa selama proses pembelajaran. Berdasarkan hasil penelitian diketahui bahwa Untuk meningkatkan kemampuan berpikir kritis siwa guru melakukan evaluasi terhadap pembelajaran yang telah berlangsung. Evaluasi yang dilakukan guru yaitu memberikan soal esai maupun uraian kepada siswa, karena dengan bentuk soal esai maupun uraian tersebut dapat merangsang siswa untuk berpikir kritis dalam memecahkan masalah yanga ada pada soal yang diberikan oleh guru. Dengan demikian, berdasarkan hal di atas bahwa evaluasi pembelajaran dapat meningkatkan kemampuan berpikir kritis siswa. Hal ini sejalan dengan pendapat Nuraida (2019:55) menyatakan bahwa memberikan latihan/evaluasi menjadikan sarana untuk mendorong proses berpikir, latihan yang dilakukan oleh siswa dapat menggambarkan kemampuan berpikir kritis siswa.

\section{SIMPULAN}

Berdasarkan analisis data dan pertanyaan penelitian yang terjawab melalui hasil temuan dan pembahasan penelitian dapat disimpulkan bahwa: Tingkat Kemampuan berpikir kritis siswa pada mata pelajaran matematika dikelas IV sekolah dasar negeri 03 Sebungkang tahun pelajaran 2020/2021 sebesar 29,58\% kategori sangat rendah. Dan diperoleh kemampuan berpikir kritis setiap indikator yaitu, (a) indikator memahami masalah matematis untuk diusulkan kategori rendah, (b) indikator mengajukan alasan logis berupa konsep atau ide sebagai bukti yang valid dan relevan kategori sangat rendah, (c) indikator menyimpulkan hubungan antara ide-ide untuk menyelesaikan masalah matematis kategori sangat rendah dan (d) indikator mengambil tindakan berupa penyelesaian masalah matematis kategori sangat rendah.

Faktor-faktor yang mempengaruhi kemampuan berpikir kritis siswa pada mata pelajaran matematika dikelas IV Sekolah Dasar Negeri 03 Sebungkang tahun pelajaran 2020/2021, diantaranya yaitu, (a) faktor psikologi belajar yang meliputi faktor 
motivasi, faktor kecemasan, dan faktor perkembangan intelektual, (b) faktor fisiologi yang meliputi kondisi fisik, (c) faktor kemandirian belajar, dan (d) faktor interaksi. Upaya guru dalam meningkatkan kemampuan berpikir kritis siwa pada mata pelajaran matematika di kelas IV Sekolah Dasar Negeri 03 Sebungkang tahun pelajaran 2020/2021, adalah (a) pengelolaan kelas, (b) menggunakan pendekatan dan metode pembelajaran yang bervariasi, (c) menciptakan interaksi antara guru dan siswa, dan (d) melakukan evaluasi pembelajaran yang dapat merangsang proses berpikir siswa yang kuat dan cepat. Adapun saran dalam penelitian ini pertama bagi guru, Hendaknya guru memperhatikan karakteristik siswa pada saat proses pembelajaran berlangsung, dimana karakter siswa bermacam ragam, seperti ada yang memahami pelajaran yang diajarkan, ada yang sedang, ada juga yang kurang, guru harus mampu meminimalisirkan hal tersebut agar tujuan pembelajaran tercapai dengan baik khususnya pada pembelajaran matematika. Kedua bagi siswa itu sendiri. Hendaknya siswa berlatih kemampuan berpikir kritisnya dengan selalu memperhatikan penjelasan guru, bertanya selama proses pembelajaran, serta berperan aktif selama pembelajaran berlangsung karena hal tersebut sangat penting mempertajam pengetahuan serta aktivitas proses belajar berlangsung dan dapat malatih kemampuan berpikir kritis.

\section{DAFTAR RUJUKAN}

Azizah. at. all. 2018 Analisis Keterampilan Berpikir Kritis Siswa Sekolah Dasar Pada Pembelajaran Matematika Kurikulum 2013. Jurnal Penelitian Pendidikan, 35(1).

Ermatiana. 2019. Analisis Kemampuan Berpikir Kritis Siswa Pada Mata Pelajaran Ilmu Pengetahuan Alam Siswa kelas IV SD Negeri 15 Kapuas Kiri Hulu Kecamatan Sintang Kabupaten Sintang Tahun Pelajaran 2018/2019. Skripsi. Sintang: STKIP Persada Khatulistiwa.

Hasbullah. 2017. Dasar-dasar Ilmu Pendidikan. Jakarta : PT rajagrafindo Persada.

Moeleong. 2016. Metode Penelitian Kualitatif. Bandung: PT Permana Rosdakarya.

Nuraida, D. 2019. Peran Guru Dalam Mengembangkan Keterampilan Berpikir Kritis Siswa Dalam Proses Pembelajaran. Jurnal Teladan, 4(1).

Prameswari. at.all. 2018. Inculcate Critical Thinking Skills In Primary Schools. National seminar elementary education, 1(1).

Purwati. 2016. Analisis Kemampuan Berpikir Kritis Dalam Menyelesaikan Masalah Persamaan Kuadrat Pada Pembelajaran Model Creative Problem Solving. Jurnal Kadikma,7(1).

Sugiyono. 2016. Metode Penelitian Kuantitatif, $K$ ualitatif, dan $R \& D$. Bandung: Alfabeta. 
Dlenggius.J.D., Dwi.C.W., Susi.S, Analisis Kemampuan Berpikir.....

Sukendo, A. 2016. Kemampuan Berpikir Kritis Dan

Kemandirian Belajar Dengan
Hasil Belajar Matematika. Jurnal Pendidikan Dasar. Vol 7. 